\title{
Manajemen Pelayanan Kampus Inklusif (Studi pada Pusat Studi dan Layanan Disabilitas Universitas Brawijaya)
}

\author{
Aldilla Reyndha Masadhe ${ }^{a *}$, Sjamsiar Sjamsuddin ${ }^{b}$, Fadillah Amin ${ }^{\mathrm{c}}$ \\ ${ }^{a b c}$ Universitas Brawijaya, Jawa Timur, Indonesia
}

\section{INFORMASI ARTIKEL}

\section{Article history:}

Dikirim tanggal: 22 Maret 2021

Revisi pertama tanggal: 26 Maret 2021

Diterima tanggal: 29 Maret 2021

Tersedia online tanggal: 14 April 2021

Keywords: management, public service, inclusive campus, persons with disabilities

\section{ABSTRACT}

This type of descriptive research using qualitative methods aims to describe and analyze the implementation of inclusive campus service management (planning, organizing, actuating, controlling) and service quality for students with disabilities at Universitas Brawijaya as an Inclusive Campus along with the supporting factors and obstacle factors of services. The results showed that the service management of the Inclusive Campus at PSLD UB has been running well, preparing competent human resources and caring for students with disabilities, implementing work programs that support services for students with disabilities (recruitment of volunteers, providing counseling and companion tutors), conducting socialization and disability awareness training for academicians, and actively providing studies on disability issues. Inclusive Campus Services in terms of quality dimensions of public services are implemented quite well; including reliability, responsiveness, assurance, empathy, and physical evidence of services. The several obstacles in the implementation of the services are; the availability of facilities and infrastructures based on the Universal Design, the weakness of planning and supervision process in the building development that are friendly for people with disabilities.

\section{INTISARI}

Jenis penelitian deskriptif dengan menggunakan metode kualitatif ini bertujuan mendeskripsikan dan menganalisis pelaksanaan manajemen pelayanan (POAC) dan kualitas pelayanan bagi mahasiswa difabel di Universitas Brawijaya beserta faktor pendukung dan penghambat pelayanan. Hasil penelitian menunjukkan manajemen pelayanan Kampus Inklusif di PSLD UB berjalan baik; dengan mempersiapkan sumber daya manusia kompeten dan peduli pada mahasiswa difabel, melaksanakan program kerja yang mendukung pelayanan (rekrutmen relawan, penyediaan konseling dan tutor), mengadakan sosialisasi dan pelatihan disability awareness untuk sivitas akademika, dan melakukan kajian tentang isu disabilitas. Pelayanan Kampus Inklusif ditinjau dari dimensi kualitas pelayanan dilaksanakan dengan cukup baik; termasuk keandalan, daya tanggap, jaminan, empati, dan bukti fisik pelayanan. Terdapat beberapa kendala dalam pelaksanaan pelayanan, terutama ketersediaan fasilitas dan infrastruktur berpedoman pada Desain Universal, serta proses perencanaan hingga pengawasan yang masih lemah dalam pembangunan gedung ramah difabel. 


\section{Pendahuluan}

Pada hakikatnya negara sebagai lembaga administrasi publik haruslah dapat melayani, serta memenuhi hak dan kebutuhan setiap warga negaranya hingga tercipta social welfare (kesejahteraan sosial). Salah satu hak setiap warga negara adalah memiliki kesempatan untuk memperoleh pendidikan. Pemenuhan hak, peluang, dan kedudukan yang setara seperti yang diamanatkan dalam UUD 1945 28C, bahwa setiap warga negara berhak memperoleh pendidikan untuk mengembangkan dan meningkatkan mutu diri, serta membangun bangsa negara, termasuk bagi penyandang disabilitas dalam memperoleh pendidikan yang setara di tingkat pendidikan tinggi. Beberapa regulasi yang melindungi hak kesetaraan pendidikan bagi penyandang disabilitas telah disusun, antara lain Konvensi Hak-Hak bagi Penyandang Disabilitas (Convention on The Rights of Persons with Disabilities) Tahun 2006 yang disahkan di Indonesia melalui Undang-Undang Nomor 19 Tahun 2011 yang di dalamnya menyebutkan tentang pendidikan inklusif; Undang-Undang Nomor 8 Tahun 2016 tentang Penyandang Disabilitas khususnya mengenai hak pendidikan bagi penyandang disabilitas dan instruksi untuk setiap penyelenggara pendidikan tinggi wajib memberikan fasilitas Unit Layanan Disabilitas; UndangUndang Nomor 20 Tahun 2003 tentang Sistem Pendidikan Nasional; Peraturan Menteri Riset, Teknologi, dan Pendidikan Tinggi (Permenristekdikti) Nomor 46 Tahun 2017 mengenai Pendidikan Khusus dan Pendidikan Layanan Khusus di Perguruan Tinggi; dan Peraturan Menteri Pekerjaan Umum dan Perumahan Rakyat Nomor 14 Tahun 2017 tentang Persyaratan Kemudahan Bangunan Gedung yang berpedoman pada Desain Universal yang mencakup kebutuhan semua orang termasuk penyandang disabilitas, anak-anak, lanjut usia, dan ibu hamil.

Setiap peraturan perundang-undangan tersebut terkait dengan penyandang disabilitas yang bertujuan melindungi hak-hak kesetaraan penyandang disabilitas terutama dalam bidang pendidikan. Pendidikan seyogyanya diselenggarakan secara inklusif, berkeadilan, menjunjung asas demokrasi serta tidak diskriminatif, dengan memprioritaskan eksistensi hak asasi manusia, nilai kultural, nilai keagamaan, dan keragaman suku bangsa. Namun pada kenyataannya, masih sangat sedikit jumlah penyandang disabilitas yang melanjutkan pendidikan hingga jenjang perguruan tinggi. Kesenjangan tampak antara jumlah lulusan sarjana penyandang disabilitas dengan yang berasal dari nondisabilitas. Berdasarkan grafik BPS pada Tahun 2019 yang dikutip dari databoks.katadata.co.id (Gambar Nomor 1); maka hanya ada 2,8\% penyandang disabilitas yang menamatkan jenjang pendidikan tinggi. Angka tersebut jauh jika dibandingkan dengan lulusan non- disabilitas yang mencapai 9,48\% (sembilan koma empat puluh delapan persen) dalam menamatkan pendidikan diperguruan tinggi. Sementara non-disabilitas yang tidak/

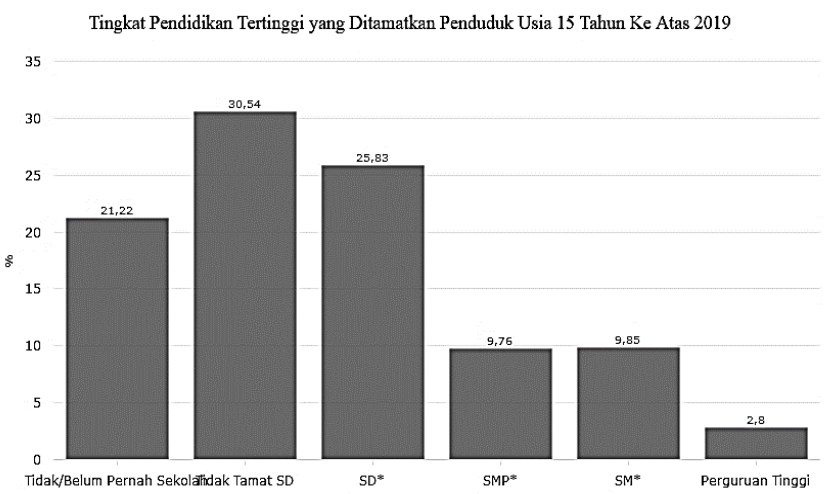

Gambar 1. Persentase Tingkat Pendidikan yang

Ditamatkan Penyandang Disabilitas di Tahun 2019 Sumber: Jayani, 2020

belum pernah sekolah hanya 3,38\%.

Hal tersebut menjadi salah satu dampak dari belum siapnya sistem pendidikan tinggi diberbagai kampus di Indonesia yang menerapkan pendidikan inklusi, serta belum terpenuhinya sarana prasarana serta infrastruktur yang aksesibel bagi penyandang disabilitas atau disebut pula dengan istilah difabel (different ability), sehingga para penyandang disabilitas menjadi kurang termotivasi untuk mengikuti jenjang pendidikan yang lebih tinggi sebab merasa terabaikan. Universitas Brawijaya sebagai salah satu perguruan tinggi negeri yang berperan sebagai penyelenggara pelayanan publik di bidang pendidikan tinggi, menjadi pelopor Kampus Inklusif di Indonesia lantaran membentuk Pusat Studi dan Layanan Disabilitas Universitas Brawijaya (PSLD UB) pada tanggal 19 Maret 2012 melalui advokasi yang dilakukan pegiat inklusivitas di Universitas Brawijaya, sehingga menghasilkan Surat Keputusan Rektor UB Nomor 135/SK/2012, serta menyelenggarakan Seleksi Program Khusus Penyandang Disabilitas (SPKPD) yang pertama kali diadakan di Tahun Ajaran 2012/2013.

Pembentukan PSLD UB beserta struktur organisasinya, dan diselenggarakannya SPKPD UB yang kini berganti nama menjadi Seleksi Mandiri Penyandang Disabilitas (SMPD UB) merupakan langkah Universitas Brawijaya dalam menjalankan amanat Undang-Undang Nomor 8 Tahun 2016 tentang Penyandang Disabilitas; khususnya pada pasal 42 ayat (3) dan (4) yang menyebutkan bahwa setiap penyelenggara pendidikan tinggi wajib memfasilitasi pembentukan Unit Layanan Disabilitas. Dalam upaya pemenuhan akan kebutuhan mahasiswa difabel (penyandang disabilitas), maka pendidikan tinggi harus ditopang penyelenggaraannya dengan ketersediaan akses, fasilitas sarana prasarana ataupun infrastruktur yang mampu mengakomodir kebutuhan dasar mahasiswa difabel dalam bingkai inklusi (Tarsidi dalam Rizky, 2015). 
Universitas Brawijaya sebagai Kampus Inklusif yang memiliki "impian besar" mencapai tingkatan World Class Entrepreneurial University (WCEU) dalam arah pengembangan kedepan sudah sepatutnya berbenah diri, salah satunya dengan menyediakan fasilitas berstandar internasional, termasuk untuk mahasiswa difabel yang direpresentasikan melalui PSLD UB beserta rangkaian manajemen untuk mengatur keberlangsungan layanan hingga paripurna untuk mendukung kelancaran studi setiap mahasiswa difabel yang berkuliah di UB. Selain itu, kualitas layanan Kampus Inklusif yang dilaksanakan PSLD UB turut menjadi fokus dalam penelitian ini, beserta faktor pendukung dan penghambat yang turut memengaruhi pelayanan bagi mahasiswa difabel di lingkungan Universitas Brawijaya. Berdasarkan hal tersebut, penelitian ini menarik dilakukan dan bertujuan untuk mengetahui, menjabarkan, menganalisis tentang implementasi manajemen pelayanan Kampus Inklusif bagi mahasiswa difabel di UB beserta dimensi pelayanan, faktor pendukung, dan faktor penghambat layanan.

\section{Teori}

\subsection{Administrasi Publik}

Felix A. Nigro \& Lloyd G. Nigro dikutip Syafiie (2006, h. 24) menyebutkan administrasi publik secara umum ialah suatu kegiatan yang dilakukan oleh sejumlah orang yang erat kaitannya dengan implementasi (pelaksanaan) kebijakan atau kebijaksanaan aparatur negara/ pemerintah, pengarahan berdasarkan kemampuan serta kecakapan (leadership) dengan menggunakan teknik-teknik dan instrumen tertentu yang tak terhingga jumlahnya demi mencapai tujuan bersama.

Salah satu paradigma dalam administrasi publik ialah Paradigma New Public Service (NPS) yang memiliki prinsip mengutamakan pelayanan kepada masyarakat, menempatkan setiap orang sebagai warga negara (as citizen), berbasis pada nilai-nilai kesetaraan dan tidak diskriminatif. Dalam paradigma NPS, administrasi publik dilakukan sebagaimana menjalankan pemerintahan yang demokratis.

\subsubsection{Pelayanan Publik}

Sinambela (2016, h. 5) mendefinisikan pelayanan publik sebagai kegiatan yang dilakukan oleh penyelenggara negara sebagai upaya pemenuhan kebutuhan masyarakat akan suatu hal. Negara didirikan oleh masyarakat (citizen) bertujuan untuk dapat meningkatkan taraf hidup ataupun kesejahteraan sosial (social welfare). Penyelenggara pelayanan publik dalam suatu negara adalah instansi pemerintahan (terdiri dari satuan kerja/ organisasi kementerian atau departemen, lembaga pemerintah non-departemen, kesekretariatan lembaga tinggi negara, dan instansi pemerintah lainnya, Badan Usaha Milik Negara, Badan Hukum Milik Negara, dan Badan Usaha Milik Daerah) termasuk yang bergerak dalam pendidikan tinggi, yaitu perguruan tinggi, akademi, politeknik, ataupun institut.

\subsubsection{Dimensi Kualitas Pelayanan Publik}

Untuk mempermudah dalam pengidentifikasian keberhasilan penyelenggaraan suatu jasa/ layanan publik, digunakanlah konsep tentang dimensi kualitas pelayanan publik (Kotler dalam Rewansyah, 2012, h. 77-79), yaitu sebagai berikut:

a) Reliability (keandalan dalam pelayanan) ialah dimensi yang berkaitan dengan kemampuan penyelenggara layanan untuk memberikan benar, cepat dan tepat atas jenis pelayanan yang telah dijanjikan kepada konsumen atau pengguna layanan, serta keterampilan menguasai produk atau jasa layanan;

b) Responsiveness (daya tanggap), yaitu kesadaran atau keinginan untuk membantu pengguna layanan dan memberikan pelayanan yang cepat atau tanggap, efektif, dan efisien. Pelayanan yang efisien akan memberikan perhatian yang optimal untuk memaksimalkan pelayanan;

c) Assurance (jaminan keamanan/ kepastian), yaitu dimensi yang berkaitan dengan pengetahuan atau wawasan dan kemampuan penyedia layanan untuk memberi jaminan keamanan serta keyakinan bagi penerima manfaat jasa layanan beserta hal-hal penjamin layanan lainnya, misalnya regulasi atau peraturan - peraturan yang menjamin;

d) Empathy (empati/ kepedulian), yaitu kemauan memberikan pelayanan melalui pendekatan personal relation. Dalam dimensi empathy, terdapat unsur hubungan antar-manusia atau interaksi, komunikasi efektif, dan kepedulian kepada pengguna layanan; dan

e) Tangible (bukti fisik layanan), yaitu segala yang bersifat kasat mata, dapat dirasakan dan disentuh oleh panca indera. Dimensi ini dapat berupa bukti fisik yang berkaitan dengan kelengkapan dan kenyamanan fasilitas sarana prasarana ataupun infrastruktur pelayanan serta peralatan dan perlengkapan penunjang pelayanan.

\subsubsection{Manajemen Publik}

Ott, Hyde, \& Shafritz (dalam Keban, 2014, h. 93) mengemukakan manajemen publik sebagai tata cara tentang penyusunan rencana pelayanan, pelaksanaan, serta penyelesaian aktivitas yang berkaitan dengan kegiatan pelayanan publik. Manajemen publik adalah proses menggerakkan sumber daya manusia dan nonmanusia sesuai instruksi kebijakan publik.

Menurut George Terry (Sule \& Saefullah, 2005, h. 9), fungsi manajemen, yaitu berikut:

a) Planning (perencanaan), yaitu serangkaian tindakan untuk mencapai sesuatu hasil yang diinginkan, berisi aktivitas menetapkan tujuan dan capaian kerja, 
perumusan strategi untuk mencapai tujuan organisasi, menentukan sumber-sumber daya yang diperlukan, dan menetapkan standar/ indikator keberhasilan dalam mencapai tujuan;

b) Organizing (pengorganisasian), yaitu serangkaian kegiatan penyusunan kerangka organisasi yang berkaitan dengan hubungan kerja atau interaksi antarsumber daya manusia dalam bekerja sama, serta adanya pembagian dan pengelompokan pekerjaan yang harus dijalankan;

c) Actuating (pelaksanaan/ penggerakan), yaitu aktivitas yang dilakukan oleh pemimpin suatu organisasi yang berwenang sebagai pengatur, pengarah, pembimbing untuk para sumber daya manusia dibawah kepemimpinannya untuk melaksanakan tanggung jawab masing-masing dalam mencapai tujuan utama organisasi. Fungsi pelaksanaan/ penggerakan ini erat kaitannya dengan kepemimpinan (leadership), hubungan antarmanusia (human relation), motivasi (motivation), dan komunikasi (communication); dan

d) Controlling (pengendalian/ pengawasan), yaitu proses untuk memastikan bahwa segala aktivitas yang terlaksana sesuai dengan yang telah direncanakan. Terdapat aktivitas penetapan standar dan metode penilaian kinerja; penilaian kinerja; membandingkan kinerja dengan standar; kemudian melakukan tindakan koreksi jika terdapat masalah.

\subsection{Manajemen Pendidikan}

Menurut Mustari (2013, h. 1) manajemen pendidikan ialah rangkaian kegiatan berupa aktivitas pengelolaan upaya kerjasama beberapa orang dalam organisasi pendidikan bertujuan untuk mencapai visi utama organisasi pendidikan secara efisien, efektif, dan berkesinambungan.

\subsubsection{Pendidikan Inklusif}

Pendidikan inklusi mengakui bahwa semua orang dari berbagai latar sosial, budaya dan karakteristik fisik, memiliki hak untuk mengakses layanan pendidikan. Menurut UNESCO (2003, h. 2-3) pendidikan inklusif dapat diartikan sebagai sistem pendidikan yang berlandaskan pada beberapa prinsip, yaitu sebagai berikut:

a) Pendidikan adalah hak asasi;

b) Tiap individu memiliki kemampuan belajar yang sama;

c) Menghargai perbedaan sebab perbedaan dapat menjadi sumber kekuatan dan kreativitas belajar, baik bagi siswa secara umum maupun guru/ dosen;

d) Penyelenggara pendidikan wajib menyediakan alat bantu/ pendukung yang mampu mengakomodisai berbagai kebutuhan pembelajaran; e) Pelaksanaan kurikulum dan asesmen berbasis individual;

f) Keanggotaan penuh (full membership) dari semua siswa tanpa kecuali di kelas reguler; dan

g) Adanya penerimaan dan dukungan dari seluruh partisipan di kelas berkaitan dengan berbagai keragaman di antara mereka.

\subsection{Klasifikasi Penyandang Disabilitas}

UU Nomor 8 Tahun 2016 tentang Penyandang Disabilitas; pada pasal 1 (satu) ayat 1 (satu) menyebutkan bahwa penyandang disabilitas adalah setiap orang yang mengalami keterbatasan fisik, intelektual, mental, dan/ atau sensorik dalam jangka waktu lama yang dalam berinterkasi dengan lingkungan dapat mengalami hambatan dan kesulitan untuk berpatisipasi secara penuh dan efektif dengan warga negara lainnya berdasarkan kesamaan hak. World Health Organization (WHO) mengklasifikasikan penyandang disabilitas menjadi tiga macam, yaitu sebagai berikut:

a) Impairment, identik dengan suatu kehilangan atau ketidaknormalan baik psikologis, fisiologis maupun kelainan struktur atau fungsi anatomis;

b) Disability, identik dengan ketidakmampuan atau keterbatasan sebagai akibat adanya impairment untuk melakukan aktivitas dengan cara yang dianggap normal bagi manusia; dan

c) Handicap, indentik dengan kesulitan atau kesukaran dalam kehidupan pribadi, keluarga dan masyarakat baik dibidang sosial ekonomi maupun psikologi yang dialami oleh seseorang yang disebabkan oleh ketidakabnormalan psikis, fisiologis (tubuh).

\subsubsection{Regulasi Penjamin Hak-Hak Penyandang Disabilitas}

a) Convention on the Rights of Persons with Disabilities (CRPD) tahun 2006 yang diratifikasi pada 30 November 2011;

b) UU RI Nomor 19 Tahun 2011 tentang Pengesahan CRPD;

c) UU RI Nomor 8 Tahun 2016 tentang Penyandang Disabilitas;

d) UU RI Nomor 20 Tahun 2003 tentang Sistem Pendidikan Nasional pasal 4 ayat (1);

e) UU RI Nomor 12 Tahun 2012 tentang Pendidikan Tinggi, Bab II tentang Penyelenggaraan Pendidikan Tinggi Bagian ke delapan pasal 32;

f) Permenristekdikti Nomor 46 Tahun 2017 tentang Pendidikan Khusus dan Pendidikan Layanan Khusus di Perguruan Tinggi; dan

g) Peraturan Menteri PUPR (Pekerjaan Umum dan Perumahan Rakyat) Nomor 14 Tahun 2017 tentang Persyaratan Kemudahan Bangunan Gedung dengan pedoman Desain Universal. 


\subsubsection{Teori Desain Universal}

Menurut Rona Mace (Pujiyanti, 2018, h. 226-228) dalam publikasi bertajuk Accessible, Adaptable, and Universal Design Tahun 1990, ialah upaya perancangan bangunan gedung dan fasilitasnya yang dapat digunakan semua orang secara bersama tanpa membutuhkan adaptasi yang berlebih dan mencakup kebutuhan masyarakat luas.

\section{Metode Penelitian}

Penelitian ini adalah jenis penelitian deskriptif dengan menggunakan pendekatan kualitatif. Pendekatan kualitatif bertujuan mengungkap suatu hal yang belum ataupun yang sedikit diketahui. Alasan penelitian ini berjenis deskriptif, yaitu karena data yang dikumpulkan berupa kata-kata, gambar, dan bukan angka-angka. Peneliti berupaya menggali bagaimana penggambaran mengenai perencanaan, pengorganisasi, penggerakan, dan pengawasan suatu fenomena yang dilaksanakan oleh objek penelitian, dalam hal ini ialah manajemen pelayanan Kampus Inklusif di Universitas Brawijaya. Selain itu, deskripsi tentang dimensi kualitas pelayanan publik (keandalan, daya tanggap, jaminan keamanan, empati, dan bukti fisik pelayanan) menjadi fokus dalam penelitian ini.

\subsection{Teknik Pengumpulan Data}

Teknik pengumpulan data yang digunakan selama penelitian berlangsung, antara lain sebagai berikut:

a) Observasi (pengamatan terhadap objek penelitian yang berkaitan dengan fokus dalam penelitian);

b) Wawancara (interview dengan narasumber yang dianggap peneliti sebagai pihak yang memiliki kapasitas dan kapabilitas dalam menjabarkan fenomena-fenomena sesuai dengan fokus penelitian); dan

c) Dokumentasi (teknik pengumpulan data secara sekunder dengan mencatat langsung data yang tersedia pada berbagai sumber data penelitian yang berhubungan dengan fokus penelitian yang tidak bisa diperoleh melalui teknik wawancara dan berfungsi sebagai informasi tambahan dalam penelitian).

\subsection{Teknik Analisis Data}

Teknik untuk menganalisis data kualitatif hasil penelitian ini menggunakan model interaktif dari Miles, Huberman, \& Saldaña (2014, h. 10). Terdapat tiga alur kegiatan setelah tahapan pengumpulan data (data collection), yaitu kondensasi data (data condensation), menyajikan data (data display), dan menarik simpulan atau verifikasi (conclusion drawing and verification).

\section{Hasil Penelitian dan Pembahasan}

\subsection{Manajemen Pelayanan di Pusat Studi dan Layanan Disabilitas Universitas Brawijaya}

Pelayanan Pusat Studi dan Layanan Disabilitas Universitas Brawijaya (PSLD UB) kepada mahasiswa difabel pada lingkungan UB telah dilaksanakan sesuai tugas dan fungsinya yang tertuang dalam Surat Keputusan Rektor Universitas Brawijaya Nomor 135/SK/2012 tanggal 19 Maret 2012. Legalitas PSLD UB tersebut mendasari pelaksanaan manajemen pelayanan Kampus Inklusif di UB bagi mahasiswa difabel. Manajemen pelayanan tersebut berupa rangkaian aktivitas manajemen; yaitu perencanaan, pengorganisasian, pelaksanaan, dan pengawasan.

Perencanaan dalam pelayanan PSLD UB telah dilaksanakan dengan melakukan identifikasi kebutuhan pelayanan bagi mahasiswa difabel, penyusunan rencana kerja tahunan yang berkorelasi dengan visi dan misi, serta tujuan unit PSLD UB, yaitu "Membangun lingkungan Universitas Brawijaya yang ramah terhadap penyandang disabilitas dan mewujudkan masyarakat Indonesia yang inklusif" dengan melibatkan unsur pimpinan universitas (Rektorat dan LP3M UB), pimpinan fakultas, mahasiswa difabel, dan mahasiswa volunteer (relawan pendamping)".

Pengorganisasian dalam pelayanan PSLD UB telah dilakukan dengan menerapkan penjabaran tugas pokok dan fungsi serta susunan dan struktur organisasi disesuaikan dengan penempatan sumber daya manusia berdasarkan kompetensi yang dimiliki masing-masing individu untuk menjalankan fungsi utama PSLD UB di bawah LP3M UB (Lembaga Pengembangan Pendidikan dan Penjaminan Mutu Universitas Brawijaya).

Pelaksanaan atau aktualisasi dalam pelayanan PSLD UB telah dilaksanakan dengan adanya keterlibatan dan dukungan dari seluruh sivitas akademika UB. Dimulai dari pimpinan universitas, pimpinan fakultas, tenaga pengajar (dosen), tenaga kependidikan (staf administrasi), dan mahasiswa berperanan dalam pelaksanaan layanan untuk mahasiswa difabel. Pelaksanaan layanan melibatkan unsur-unsur dalam manajemen, yaitu man, money, materials, machines, methods, market, dan information. Semua terhubung untuk mewujudkan Universitas Brawijaya sebagai Kampus Inklusif ramah difabel.

Pengawasan atau pengendalian dalam pelayanan PSLD UB telah dilaksanakan oleh perangkat unit kerja PSLD UB. Pengawasan atau pengendalian yang diterapkan PSLD UB, yaitu evaluasi akademik mahasiswa difabel (identifikasi capaian nilai akademik 
dan masa studi mahasiswa); evaluasi kegiatan workshop atau sosialisasi yang melibatkan sivitas akademika UB; evaluasi volunteer (pendamping mahasiswa difabel); evaluasi kecukupan sumber daya manusia pada PSLD UB; dan evaluasi secara menyeluruh terkait program kerja dalam satu tahun anggaran yang dilakukan diakhir tahun anggaran.

\subsection{Kualitas Pelayanan bagi Mahasiswa Penyandang Disabilitas di Universitas Brawijaya}

Dimensi kualitas pelayanan turut menjadi fokus penelitian ini, antara lain dimensi keandalan, daya tanggap, jaminan keamanan/ kepastian layanan, empati, dan bukti fisik pelayanan. Keandalan (reliability) dalam memberikan pelayanan kepada mahasiswa difabel dilingkungan UB telah dimiliki oleh setiap sumber daya manusia pada masing-masing bidang di PSLD UB sesuai dengan kompetensi setiap personel. Selain itu, dimensi kualitas pelayanan yang berkaitan dengan "keandalan" juga ditunjukkan oleh tenaga pengajar (dosen), tenaga kependidikan (staf administrasi) dan mahasiswa relawan pendamping (volunteer) dalam memberikan layanan kepada mahasiswa difabel, meskipun belum terpenuhi secara optimal.

Daya tanggap (responsiveness) dalam pelayanan kepada mahasiswa difabel telah dilaksanakan oleh sumber daya manusia diunit kerja PSLD UB, yaitu dalam bentuk pengadaan rekrutmen relawan pendamping, konseling kepada mahasiswa yang memiliki permasalahan akademik atau pergaulan dikampus, melakukan upaya advokasi terhadap pemenuhan fasilitas kampus yang aksesibel bagi difabel, upaya pendekatan personal yang dilakukan tenaga pengajar (dosen) kepada mahasiswa difabel (memberi waktu ekstra bagi mahasiswa difabel untuk lebih memahami materi kuliah), serta ketanggapan relawan pendamping dalam mendampingi aktivitas dan mobilitas mahasiswa difabel di lingkungan kampus.

Jaminan keamanan atau kepastian (assurance) yang telah dilaksanakan PSLD UB beserta sivitas akademika UB melalui komitmen bersama untuk selalu menghadirkan suasana inklusi di UB, mengesahkan peraturan yang melindungi hak-hak mahasiswa difabel melalui SK Rektor UB 135/SK/2012 tertanggal 19 Maret 2012, menetapkan tata cara pendampingan untuk mahasiswa difabel, manual prosedur layanan konseling, manual prosedur rekrutmen dan pelatihan pendamping, dan manual prosedur tutorial dan pendampingan tugas akhir.

Empati (empathy) adalah unsur dimensi kualitas pelayanan kepada mahasiswa difabel di lingkungan UB yang ditunjukkan melalui kepedulian PSLD UB dalam menyelenggarakan pelayanan serta berupaya untuk terus menularkan disability awareness (kesadaran terhadap keberadaan dan hak-hak penyandang disabilitas) kepada setiap sivitas akademika UB untuk selalu mewujudkan Kampus Inklusif.

Bukti fisik (tangible) dalam pelayanan Kampus Inklusif bagi mahasiswa difabel di UB berupa sarana prasarana dan infrastruktur penunjang aksesibilitas mahasiswa difabel. Masih banyak ditemukan ketidaksesuaian antara wujud fasilitas atau infrastruktur dengan standar desain universal yang aksesibel bagi semua orang, termasuk difabel. Misalnya, toilet khusus difabel yang tidak tersedia disetiap gedung atau bangunan di UB, keberadaan jalur ramp bagi pengguna kursi roda yang kerap dijadikan tempat parkir atau benda lainnya, guiding block (ubin bertekstur) yang belum terhubung antara bangunan satu dengan lainnya.

\subsection{Faktor Pendukung dan Faktor Penghambat Layanan}

Hasil dari penelitian ini mengemukakan beberapa faktor pendukung yang sampai sejauh ini menyokong kelancaran pelayanan, diantaranya ialah keandalan dan kesigapan, kompetensi, serta pengalaman yang dimiliki oleh sumber daya manusia di PSLD UB sebagai penguat tim pelaksana layanan. Selain itu, UB sebagai pioneer Kampus Inklusif memperkuat motivasi untuk selalu memberikan pelayanan paripurna bagi mahasiswa difabel. Adanya regulasi atau peraturan yang melindungi secara legal keberadaan PSLD UB menjadi komitmen yang ditunjukkan oleh jajaran pimpinan UB dalam menjunjung tinggi inklusivitas. Hal terpenting lainnya adalah eksistensi relawan pendamping dan unit aktivitas mahasiswa (FORMAPI, Eksekutif Mahasiswa UB, Badan Eksekutif Mahasiswa UB) yang konsisten mendampingi aktivitas dan mobilitas serta aktif melakukan advokasi tentang kebutuhan mahasiswa difabel dalam menempuh pendidikan di UB.

Meskipun keberadaan faktor pendukung yang selama ini menjadi supporting system bagi pelayanan Kampus Inklusif bagi mahasiswa difabel dilingkungan UB; namun terdapat faktor penghambat yang ditemukan melalui penelitian ini, antara lain disability awareness (kesadaran tentang keberadaan penyandang disabilitas) yang belum dimiliki sepenuhnya oleh seluruh sivitas akademika UB. Legalitas atau aturan-aturan yang disahkan, unit layanan disabilitas sudah dibentuk, tenagatenaga kompeten sudah dipilih, namun jika disability awareness tidak diterapkan setiap sivitas akademika UB, maka keberadaan Kampus Inklusif bisa saja tergerus. Selain itu, fasilitas dan infrastruktur yang sesuai dengan desain universal dan aksesibel bagi difabel belum terpenuhi secara merata pada bangunan atau fasilitas di UB. 


\section{Kesimpulan}

\subsection{Kesimpulan}

Manajemen dalam menjalankan pelayanan Kampus Inklusif sebagai upaya PSLD UB dalam memenuhi kebutuhan mahasiswa difabel dilingkungan UB sudah berjalan sesuai dengan alur dan fungsi manajemen, yaitu merencanakan dan mencanangkan program kerja, menyusun dan membagi tugas dan peran sesuai dengan struktur organisasi, menggerakkan sumber daya manusia di PSLD UB sesuai dengan tugas pokok dan fungsinya dalam pelayanan kepada mahasiswa difabel, serta melakukan evaluasi terhadap pelayanan ataupun aktivitas yang berkaitan dengan perwujudan Kampus Inklusif di UB.

Kualitas pelayanan yang dilakukan PSLD UB sebagai ujung tombak dalam memberikan layanan kepada mahasiswa difabel dilingkungan UB dapat dilihat dari lima dimensi kualitas pelayanan, yaitu keandalan, daya tanggap, jaminan keamanan, empati, dan bukti fisik layanan.

Faktor pendukung merupakan "nilai tambah" yang harus diperhatikan dan dipertahankan oleh seluruh sivitas akademika UB, sehingga faktor-faktor pendukung tersebut dapat terus menjadi pemantik semangat dan motivasi dalam pelayanan bagi mahasiswa difabel, serta untuk selalu konsisten mewujudkan UB sebagai Kampus Inklusif dan mendukung pembangunan manusia. Sedangkan faktor-faktor penghambat dalam penyelenggaraan pelayanan Kampus Inklusif merupakan kendala yang harus segera diantisipasi dan/ atau diselesaikan sebelum berpotensi menjadi masalah yang lebih kompleks. Penyelesaian potensi permasalahan tersebut menjadi pekerjaan rumah sekaligus tantangan bagi pihak-pihak yang berwenang dalam pengambilan keputusan, serta menjadi tanggung jawab seluruh sivitas akademika UB untuk mewujudkan inklusivitas dalam dunia pendidikan.

\subsection{Saran}

Berdasarkan hasil penelitian ini, beberapa saran ditawarkan sebagai langkah preventif bagi UB sebagai penyedia pelayanan Kampus Inklusif. Diantaranya, peningkatan intensitas sosialisasi tentang disability awareness yang menyentuh seluruh lapisan sivitas akademika UB; bagi tenaga pengajar seharusnya mampu memahami dan menyiapkan materi atau metode pembelajaran inklusif; tenaga kependidikan agar dapat menunjukkan performa pelayanan yang lebih baik dan bersahabat; serta seluruh mahasiswa dilingkungan UB untuk selalu menumbuh-kembangkan sikap friendly tanpa sekat stigma dan diskriminasi kepada rekan mahasiswa difabel.

Peningkatan identifikasi kebutuhan mahasiswa difabel secara terperinci dengan melibatkan mahasiswa difabel, perwakilan unsur pimpinan atau senat, tenaga pengajar, tenaga kependidikan kemudian dituangkan dalam proses perencanaan dan dilanjutkan dengan pengusulan perencanaan kepada stakeholder atau pihak yang berwenang dalam pengambilan keputusan.

Peningkatan keseriusan dalam pembenahan fasilitas dan infrastruktur berpedoman pada Desain Universal, serta bila memungkinkan, melibatkan unit kerja PSLD UB dalam pertimbangan dan pengawasan pembangunan fasilitas dan infrastruktur yang aksesibel bagi difabel.

\section{Daftar Pustaka}

Jayani, Dwi Hadya. (2020). Hanya 2,8\% Penyandang Disabilitas Menamatkan Perguruan Tinggi: Tingkat Pendidikan Tertinggi yang Ditamatkan Penduduk Usia 15 Tahun Ke Atas 2019. Diakses 20 Februari 2020, dari https://databoks.katadata.co.id/datapublish/2020/0 2/07/hanya-28-penyandang-disabilitasmenamatkan-perguruan-tinggi

Keban, Y.T. (2014). Enam Dimensi Strategis Administrasi Publik Konsep, Teori dan Isu Edisi Ketiga. Yogyakarta: Gavamedia.

Miles, M. B., Huberman, A.M., and Saldaña J. (2014). Qualitative Data Analysis: A Methods Sourcebook 3rd Edition. USA: SAGE Publ.

Mustari, M. (2013). Manajemen Pendidikan dalam Konteks Indonesia. Bandung: Arsad Press.

Pujiyanti, I. (2018). Implementasi Universal Design Pada Fasilitas Pendidikan Tinggi. Jurnal Arsitektur dan Perencanaan, 1(2), 223-239.

Rewansyah, A. (2012). Kepemimpinan dalam Pelayanan Publik. Jakarta: PT. Rizky Grafis.

Rizky, U.F. (2015). Kebijakan Kampus Inklusif Bagi Penyandang Disabilitas (Studi tentang Advokasi Kebijakan Kampus Inklusif di Universitas Brawijaya). Indonesian Journal of Disability Studies, 2(1), 1-8.

Sinambela, L.P. (2016). Reformasi Pelayanan Publik: Teori, Kebijakan, dan Implementasi. Jakarta: PT Bumi Aksara.

Sule, E.T., \& Saefullah, K. (2005). Pengantar Manajemen. Jakarta: Kencana.

Syafiie, I.K. (2006). Ilmu Administrasi Publik. Jakarta: Rineka Cipta. 